\title{
A SEQUENCE OF MARINE TERRACES NEAR LATINA (AGRO PONTINO, CENTRAL ITALI)
}

\author{
J. Sevink, P. Vos, W.E. Westerhof, A. Stierman \& H. Kamermans, Amsterdam
}

\section{SUMMARY}

A detailed physiographic soil survey has been carried out in the NW part of the Agro Pontino, near Latina. Four marine terraces and extensive eolian sand covers were found. The oldest marine terrace, the Latina complex, largely consists of augitic fine sands of marinelagoonal origin. Towards the end of the transgression (of uncertain age) some minor sea leve fluctuations occurred. The next marine terrace, the Minturno complex, is thought to date from the Tyrrhenian II transgression and was preceded by a major regression. This has the characteristics of a normal transgressive system, including late minor sea level fluctuations. The beachridge and lagoonal deposits are slightly tilted to the SW and are underlain by littoral gravels, most probably derived from the adjacent Latina complex through strong abrasion. Following a minor regression another marine terrace was formed (the Borgo Ermada com plex). This terrace is considered to date from the Tyrrhenian III transgression, buthas a regres sive character, a phenomenon which can be explained by assuming a synformational tectonic tilting, some evidence for which is found. During a subsequent major regression (Würmian) eolian sands were repeatedly deposited, particularly on the Borgo Ermada complex. This was followed by the formation of a simple beachridge-lagoon system during the Holocene (the Terracina complex). The datings are based on correlation with sequences elsewhere, the two marine faunas studied give no clue as to their ages.

Soil formation depends strongly on the texture of the parent materials and these relationships are indicated schematically. Soils in sands form a clear chronosequence, exhibiting an increased rubefaction and illuvial concentration of clay with age (Regosols - Arenosols - Luvisols). The distinction between the Borgo Ermada and Minturno complex is partly based on this chronosequence. Soils with a sandy albic E horizon, more or less abruptly overlying a stagnative clayey B horizon (Planosols and related soils) abound in intermediate materials of the Pleistocene terraces. The characteristically abrupt textural change was found to be due to the heterogenity of the parent material (eolian sand over loam to clay) rather than to soil formation.

Some attention is paid to prehistoric artefacts, in particular Pontinian type tools and observations of BLANC on the famous site of Gniff-Gnaff are reinterpreted.

\section{INTRODUCTION AND GENERAL INFORMATION}

The area studied is located near Latina (see figure 1), about $70 \mathrm{~km} \mathrm{~S}$ of Rome and forms part of the Agro Pontino. Altitudes range from about $25 \mathrm{~m}$ a.s.l. to slightly below sea level near the coast. Prior to World War II the low lying areas had been drained and partly reclaimed. Large areas have been and are still raised with materials obtained through building activities in Latina and by dredging the large drainage canals, in particular the Fosso del Moscarello. Climate can be described as attenuated to accentuated meso-mediterranean (UNSECO-FAO 1963). The mean annual precipitation is $800-900 \mathrm{~mm}$ and the soil moisture regime according to the SOIL TAXONOMY (1975) is xeric. 


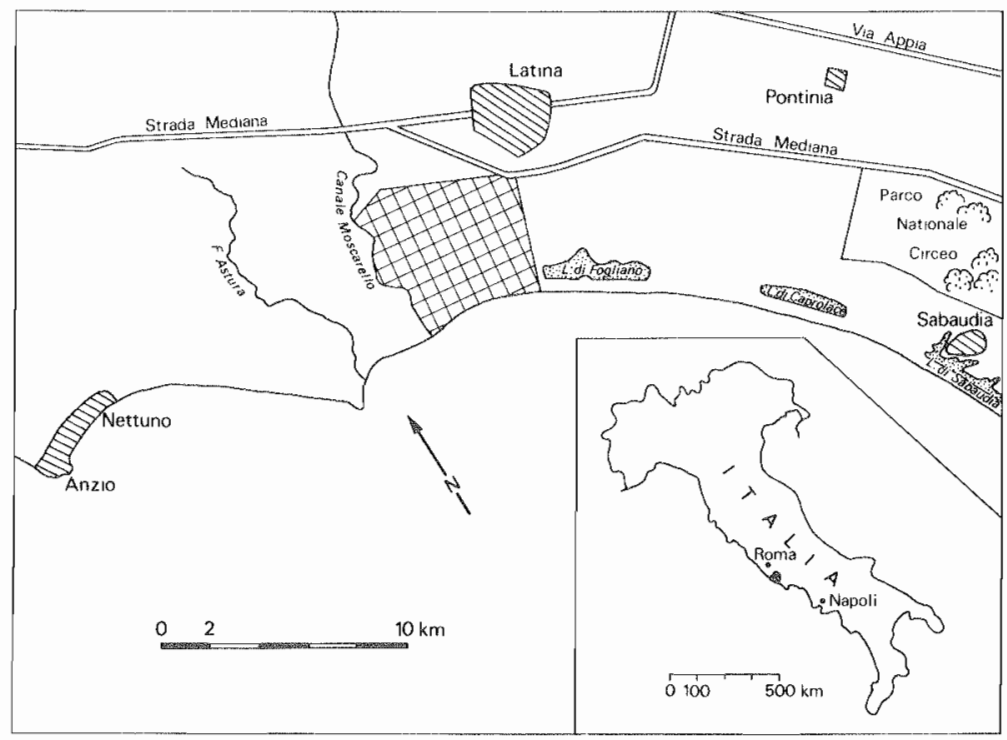

Fig. 1: Location of the area studied.

According to the older literature (BLANC 1936a, BLANC 1962, geological maps scale 1:100.000 and accompanying memoirs, sheets Latina, Frosinone and Terracina) a narrow coastal strip is underlain by Holocene beach ridge and lagoonal deposits and most of the area by older, predominantly colian, sands. These deposits cover a thick complex of Quaternary marine-eolian deposits, which have only been studied in a few borings and are nowhere exposed. They are described by terms such as "marine", "continental" etc. and are dated as "PostSiciliano", "Siciliano" and "Calabriano" on the basis of the shell fauna (CONFORTE et al.). More recent research (DESSING 1972, SEVINK 1977, REMMELZWAAL 1978) has shown that near Latina, a hitherto unknown series of well developed marine terraces with associated eolian deposits can be distinguished.

In this paper some results are presented of a detailed soil survey carried out by the present authors in the area southwest of Latina. An attempt has been made to reconstruct the Quaternary evolution and to correlate the various phases of erosion and sedimentation with those observed elsewhere along the Tyrrhenian coast.

The Agro Pontino is noted for its prehistoric remnants, particularly those from the Pontinian (Middle Paleolithic), which have been extensively studied and described by BLANC. The "type locality" for the Pontinian lies at Gniff-Gnaff (see figure 2). Unfortunately the stratigraphic relation of the deposits described by BLANC(BLANCetal. 1957) with those constituing the marine terraces to the SE, is not known. Attention is paid to the flint artefacts encountered in the topsoils during the survey, as well as to a reinterpretation of the observations of BLANC on this "type locality". 


\section{METHODS}

Augerings were carried out by hand to depths ranging from $1.2 \mathrm{~m}$ to approx. $5 \mathrm{~m}$, along five sample lines set out perpendicular to the coast. One of the sample lines was surveyed with a water level (see figure 3). On the basis of the information obtained in this way a physiographic airphoto interpretation for a soil map (scale 1:25.000) was carried out, which was subsequently checked in the field. In order to establish the stratigraphic relation between the different major units, additional augerings were made. Samples were taken from shell-bearing sediments, encountered in deep pits or during groundwater drillings.

The soils were named after the legend for the Soil Map of the World (FAO-UNESCO 1974) and partly, after the SOIL TAXONOMY (1975). The colour codes used are from the Soil Munsell Color Charts.

The soil and sediment analyses have been taken from earlier publications and internal reports. For a description of the analytical methods reference is made to REMMELZWWAL (1978).

\section{OBSERVATIONS}

The area basically consists of four marine complexes: the Terracina, Borgo Ermada, Minturno and Latina complexes (SEVINK 1977, REMMELZWAAL 1978). These have been more or less dissected and covered by eolian sands. The incisions have been partly filled in by colluvio-alluvial deposits. In figure 2 a map is presented showing the distribution of the various physiographic units and related sediments. Each of these units will be separately described.

Prior to this description a few remarks have to be made about the conditions of sedimentation in Mediterranean coastal areas. In contrast to oceanic coastal areas, tidal influences play a very subordinate role. As a result the boundary between high energy (littoral and beach ridge environment) and low energy (lagoonal to lacustrine environment) deposits is usually very sharp and well pronounced, particularly in areas with negligible fluvial supply. Bimodal grainsize distributions of lagoonal sediments under these conditions can nearly always be ascribed to the addition of eolian sand during their genesis. This is particularly evident from the analyses presented in figure 6 . Recent transport of eolian sand across a lagoonal plain is in fact frequently observed along the Tyrrhenian coast.

A second complication is that due to strong soil formation in the older deposits the stratification, as well as fossils if originally present, have disappeared in the upper metres and the texture has been more or less altered.

\subsection{THE TERRACINA COMPLEX}

This complex has a rather simple structure: a recent beachridge with eolian top and a lagoonal area, roughly at sea level. The lagoon, through earlier fluvial incisions, extends into the Borgo Ermada Complex. The beachridge is composed of well-sorted calcareous sands (see profile 217, figure 6), which, as is illustrated by the cross section (see figure 3), have been locally blown over the lagoonal deposits. This phenomenon is particularly evident near Foce Verde, where the lagoonal sediments in some places are completely covered by eolian sands.

The lower parts of the lagoon often have been raised by man. As a result of these activities 


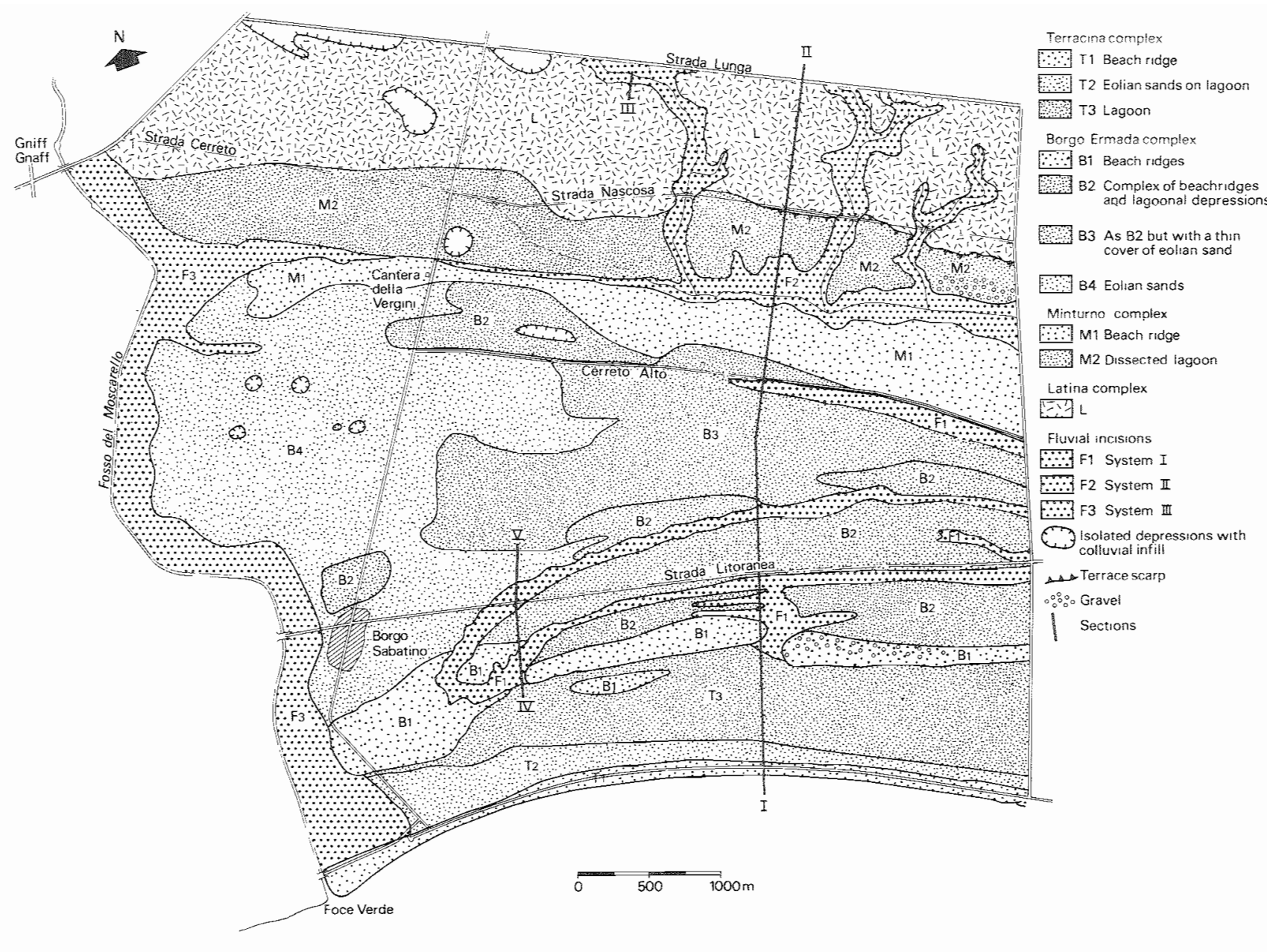

Fig. 2: Physiographic map of the area studied. 
SW TERRACINA LEVEL

BORGO ERMADA LEVEL

MINTURNO LEVEL

LATINA LEVEL

NE

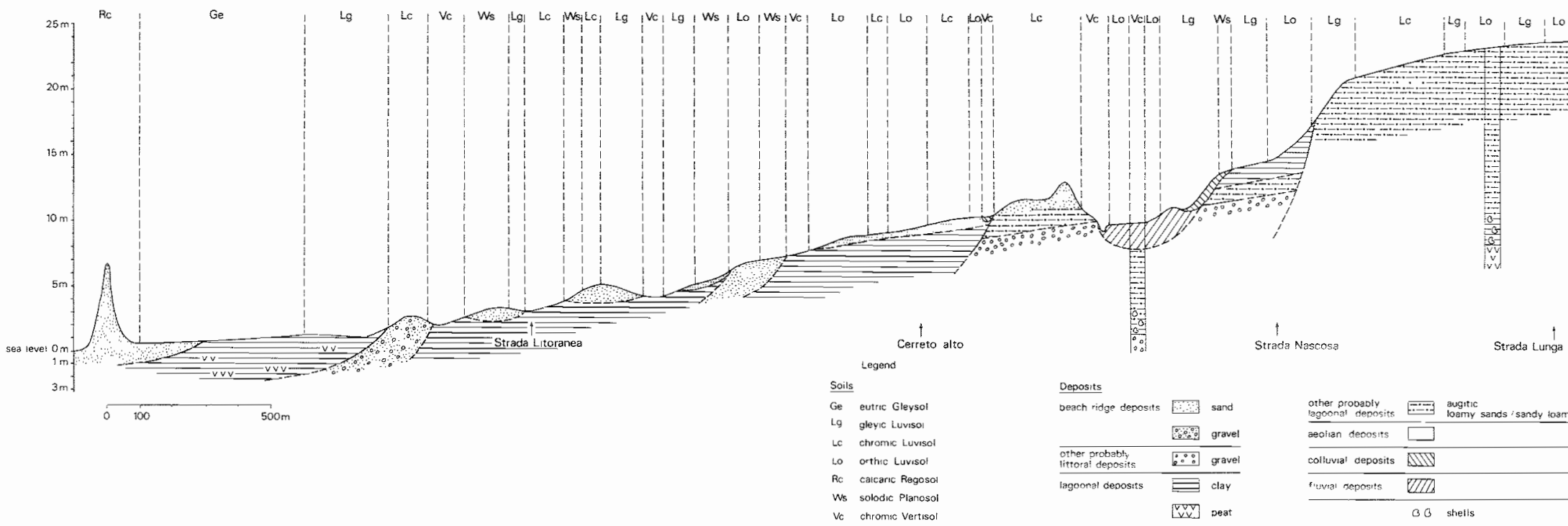

Fig. 3: Sediments and soils in section $I-$ II 
the original pattern of sedimentation has been disturbed and remains rather obscure. Noncalcareous clays, which in the subsoil are only partially ripened and in several augerings appeared to be underlain by marine sands, prevail in the central part of the lagoon, whereas in the incisions in the Borgo Ermada complex (see figures 3 en 4 ) peats and peaty clays occur, also with a partially ripened subsoil.

The soils in this complex are weakly developed. They consist of sandy AC profiles in the beachridge deposits, classified as Calcaric Regosols, and elsewhere of clayey to peaty noncalcareous, fine-textured soils with hydromorphic properties within $50 \mathrm{~cm}$ and with at most a weakly developed cambic B-horizon. Most of the latter soils can be classified as Eutric Gleysols, but Histosols and Eutric Fluvisols occur rather frequently.

Paleosols were observed only in the beachridge and consist of overblown weakly developed soils (at most Cambic Arenosols, but mainly Regosols). The identification of the boundary with the Borgo Ermada complex poses no problems as the soils in the Borgo Ermada complex are completely ripened, well developed soils, free of any peaty material. Furthermore, the lagoonal deposits are separated from the deposits of the Borgo Ermada complex by a clear discordance.

\subsection{THE BORGO ERMADA COMPLEX}

As indicated by figure 2 as well as by the cross sections (figures 3 and 4 ) this is a complicated system in which four subunits can be distinguished. Unit B1 consists of relatively pronounced elongated ridges, reaching altitudes of 2-3 ma.s.l. The upper few metres are composed of well-sorted pedogenetically altered fine sands (see figure 6, sample 245). In a few deep borings for groundwater, the sands appeared to grade into fossiliferous fine to medium textured marine sands of unknown thickness. Paleosols were not encountered in these borings. In the SE part of this unit coarse sandy gravel beds locally abound (see figure 2). The gravel is well rounded and sorted and mainly consists of chert. Elsewhere such gravelly intercalations were seldom encountered. The soils are Chromic Luvisols with well-developed 7.5 YR coloured argillic horizons and with a solum of roughly $2 \mathrm{~m}$ thickness. Pseudo-gley is lacking. Near Foce Verde the ridges become less pronounced and eolian depressions occur. The Luvisols here appeared to be locally covered by sands with 7.5 to 10 YR coloured Cambic Arenosols.

Unit B2 consists of an intricate pattern of small elongated sandy ridges, ranging in altitude from $2 \mathrm{~m}$ a.s.l. near unit $\mathrm{B} 1$ to $9 \mathrm{~m}$ a.s.l. in the NE, and of depressions with completely ripened clays. Borings near the edges of the ridges showed the sands to thin out over the clays (see figure 4) while in a few deeper augerings in the centres of the ridges clays, similar to those found in the depressions, were observed underneath the sands. The soil pattern in this unit is complicated: on the sandy ridges an often rapid alternation of Chromic, Orthic and Gleyic Luvisols occurs (see figure 4). Planosols dominate in the transitional zone (sand on sandy clay loam to clay), while in the depressions Chromic Vertisols were observed. This sequence may occur within a distance of less than $50 \mathrm{~m}$ (see figure 4). In figure 6 grainsize analyses of a Solodic Planosol in intermediate position are presented (profile 306). The Gleyic Luvisols, if in transitional position, frequently contain exceptional amounts of Fe-Mn nodules in an argillichorizon with strong pseudogley phenomena.

Unit $\mathrm{B} 3$ can be described as well-sorted, presumably eolian, fine sands, forming a slightly undulating and discontinuous cover on top of a complex of elongated fine sandy ridges and clayey depressions, comparable to unit B2, but with a less pronounced relief. Altitudes range 


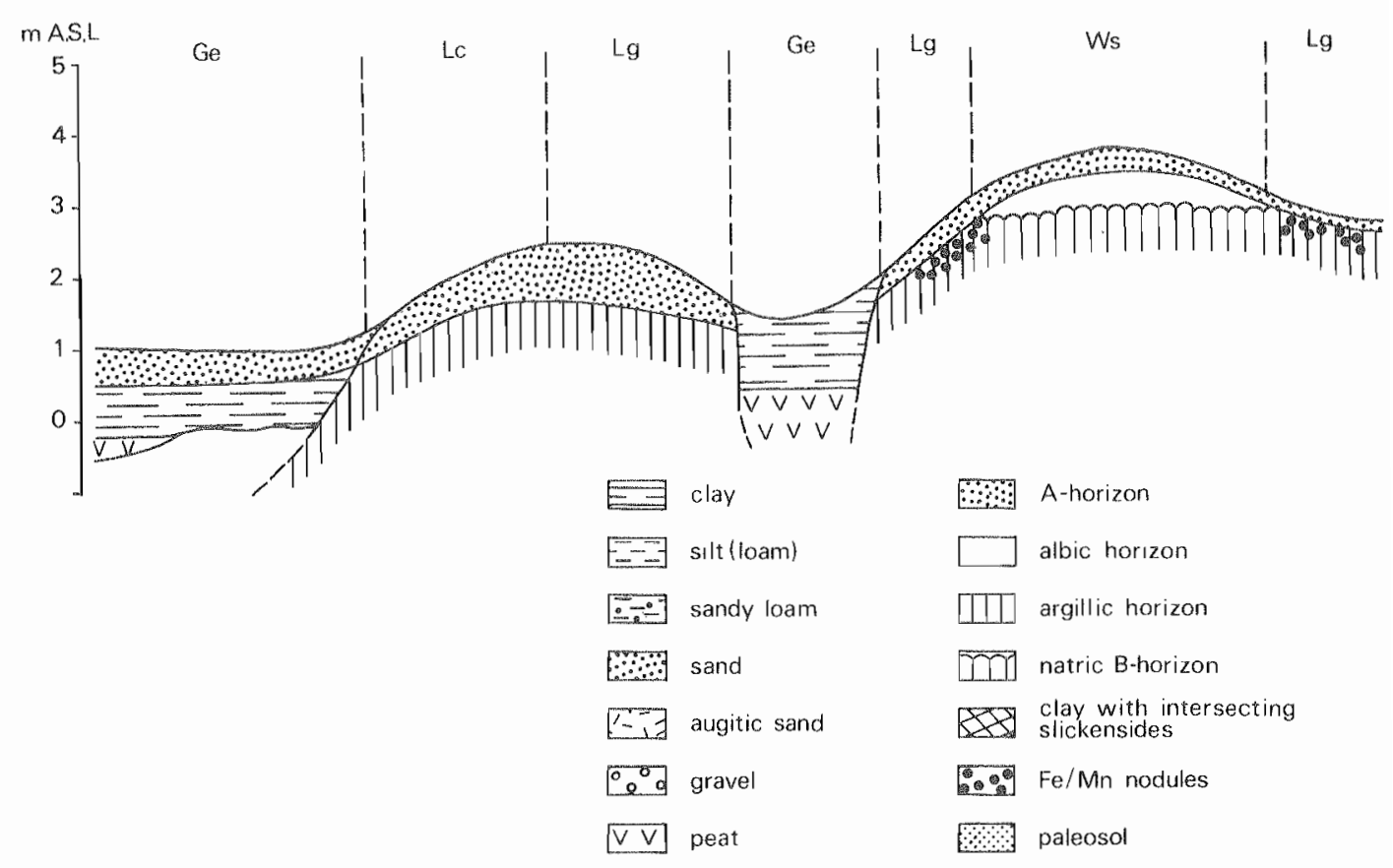

Fig. 4: Sediments and soils in section IV - V

from approx. $4 \mathrm{~m}$ to $9 \mathrm{~m}$ a.s.l. near the Minturno complex. The thickness of the sand cover is generally less than one metre and stratification is lacking due to post-depositional soil formation. The soil horizons, developed in the overlying sands, are always bleached ( $\mathrm{E}$ horizons). Transitions towards underlying clayey sediments are always abrupt. In the underlying clay at several sites polygonal cracks were observed, filled in by the overlying sands. The soils are Albic and Gleyic Luvisols (sand on sand to loam) and Solodic Planosols (sand on sandy clay loam to clay). Clear evidence for the occurrence of buried soils was nowhere observed. The sand cover thins out to the SE, whereas towards unit B4 its thickness increases.

In unit B4 the eolian sand cover, which has a clear eolian relief, is nearly continuous and is often more than one metre thick. It covers earlier fluvial incisions and altitudes range from 5 to 10 ma.s.l. Cambic Arenosols to Chromic Luvisols with moderately developed argillichorizon prevail and locally intercalated paleosols of similar nature were observed. Older deposits forming part of the Borgo Ermada complex outcrop locally or, more frequently, were encountered in augerings. They were recognized as such by the soils they contain which have a similar range in texture and other properties as those in units $\mathrm{B} 1$ and $\mathrm{B} 2$.

The transition towards the next higher unit - the Minturno level -is rathergradual. In the NW it is obliterated by the eolian sands butstill recognizable as a slope discontinuity. To the SE this slope discontinuity becomes more pronounced. The major criterium for distinguishing the two complexes is the soil formation, the Minturno complex being characterized by the occurrence of a characteristic deep Ferric Luvisol, also encountered as a buried soil in the transitional zone (see for example figure 5). 


\subsection{THE MINTURNO COMPLEX}

This complex consists of an elongated ridge 8 to $15 \mathrm{~m}$ a.s.l. and a posterior dissected level area, 11 to $16 \mathrm{~m}$ a.s.l. The main incision runs immediately behind and parallel to the ridge. The ridge is characterized by the occurrence of deep (about $4 \mathrm{~m}$ ) reddish-brown soils with a strongly developed argillic B-horizon and with abundant iron-manganese mottles and nodules in its lower part. Textures range from sandy clay loam to sandy loam or loamy coarse sand in the subsoil (see analyses of profile 359, figure 6). The deposits frequently contain some gravel and because of their rather poor sorting and morphology, represent a beachridge system, rather than a beach-dune system. In later incisions along the NEboundary of the ridge the sands were observed to overlie greenish clays with pronounced vertic properties. Obviously in a late stage the beachridge migrated inland over the lagoonal sediments (see figure 5). The greenish nonstratified clays also form the top of the deposits in the dissected level area, and, in the subsoil, locally still contain shells and corals.

Observations from foundation pits in the deep laterfluvial incisions and in agravel pitjust outside the area studied, show that the clays lie on loams and subsequently on gravels without unconformities and in addition that this sequence exhibits a distinct "fining upwards". Immediately underneath the clay stratification is lacking. In the more elevated NWpart underneath the clay a thin buried soil with a weakly developed reddish brown mottled argillic horizon was observed locally. Elsewhere, however, such paleosols are lacking and here the distur. bance of the original stratification can be ascribed to soil forming processes, in particular churning. The observations indicate that the thickness of the clay layer decreases to the SE, where it is generally about $2 \mathrm{~m}$ thick. The gravels mainly consist of well-sorted and rounded flint and are parallel bedded. The beds have a low-angle dip to the SW.

Additional information on the deeper strata in the level area comes from the large gravel pit mentioned above and is shown in figure 3. Characteristicis the occurrence of gravel to boulder size tuff and tuffaceous sandstone fragments with abundant lithodome bore holes. Alist of the molluscs observed is presented in table 1 .

In figure 5 a cross section is given based on observations in a deep drainage ditch through the sandy ridge and on additional augerings. It shows that underneath the ridge the same sequence is present as in the level area. Furthermore, in the greenish clay underneath the sands, a buried vertisol was observed.

Soils in the sandy ridge, as stated before, are deep Ferric Luvisols with strong accumulation of Fe-Mn as mottles and concretions. Most soils are more or less truncated, in some instances to such a degree that they should be classified as Chromic or Orthic Luvisols. In figure 6 , analyses of such a soil are presented (profile 359). Soils in the level area range from Solodic Planosols (presence of a thin layer of sandy albic material) to Chromic Vertisols. No clear pattern could be observed in the distribution of the sandy top layer (for the analyses of a Solodic Planosol, see figure 6, Latina I). On the slopes of the incisions a large variety of soils is present, ranging from Chromic Vertisols in clay, Gleyic Luvisols in loams to Gleyic Cambisols in loamy gravels. In unit M2 the pattern is further complicated by human activity directed towards the improvement of the extremely unfavourable physical properties of the soils.

In the transitional zone between unit M1 and M2, soils with a textural profile of sand on clay loam or clay often exhibit extreme pseudogley phenomena including intense accumulation of $\mathrm{Fe}$ and $\mathrm{Mn}$ in concretions. 


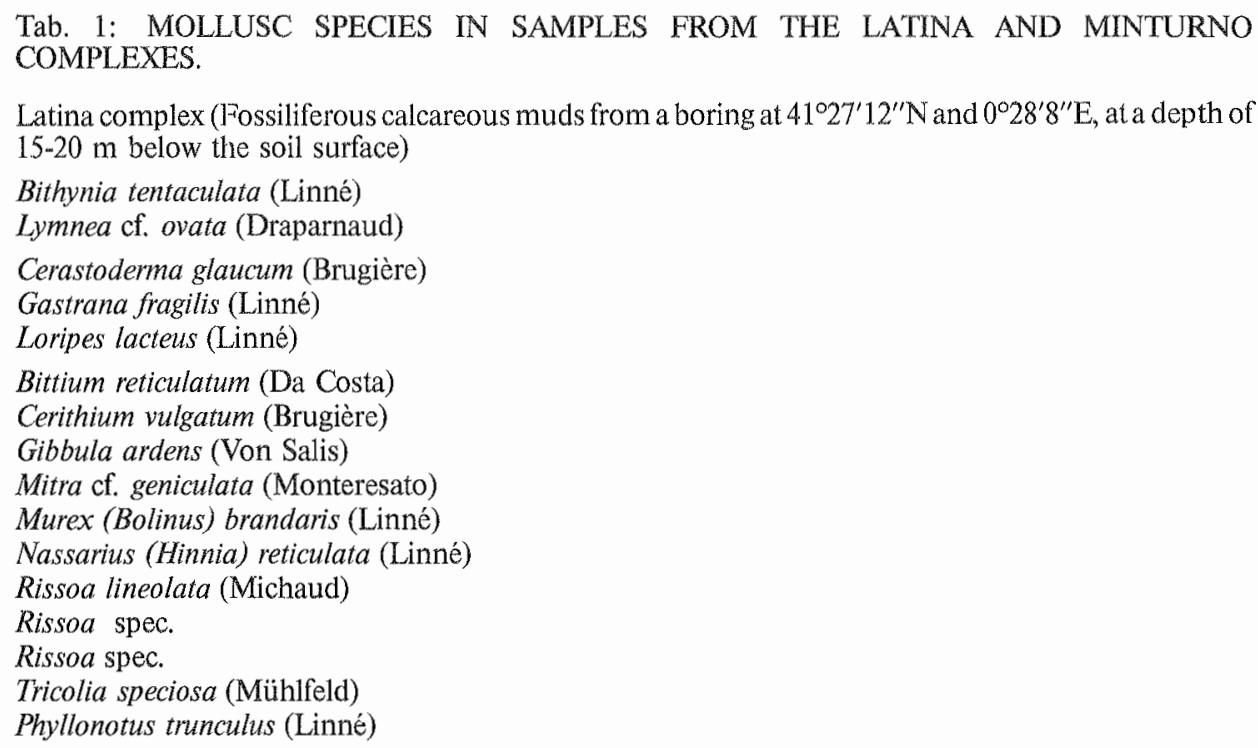

Latina complex ( $\mathrm{F}^{\circ} \mathrm{ossiliferous} \mathrm{calcareous} \mathrm{muds} \mathrm{from} \mathrm{a} \mathrm{boring} \mathrm{at} 41^{\circ} 27^{\prime} 12^{\prime \prime} \mathrm{N}$ and $0^{\circ} 28^{\prime} 8^{\prime \prime} \mathrm{E}$, at a depth of $15-20 \mathrm{~m}$ below the soil surface)

Bithynia tentaculata (Linné)

Lymnea cf. ovata (Draparnaud)

Cerastoderma glaucum (Brugière)

Gastrana fragilis (Linné)

Loripes lacteus (Linné)

Bittium reticulatum (Da Costa)

Cerithium vulgatum (Brugière)

Gibbula ardens (Von Salis)

Mitra cf. geniculata (Monteresato)

Murex (Bolinus) brandaris (Linné)

Nassarius (Hinnia) reticulata (Linné)

Rissoa lineolata (Michaud)

Rissoa spec.

Rissoa spec.

Tricolia speciosa (Mühlfeld)

Phyllonotus trunculus (Linné)

Minurno complex (Fossiliferous beds from a gravelpit at $41^{\circ} 26^{\prime} \mathrm{N}$ and $0^{\circ} 26^{\prime} 20^{\prime \prime} \mathrm{E}$, at a depth of $10 \mathrm{~m}$ )

Aequipecten opercularis (Linné)

Pecten lacobaeus (Linné

Cardium tuberculatum (Linné)

Glycemeris violacecens (Lamarck)

Ostrea edulis (Linné)

Astrea rugusa (Linné)

Cassidaria echinophora (Linné)

Cerithium vulgatum (Brugière)

Charonia opis (Röding)

Cymatium corrugatum (Lamarck)

Murex brandaris (Linné)

Natricarius stercusmuscarum (Gmelin)

Phyllonotus trunculus (Linné)

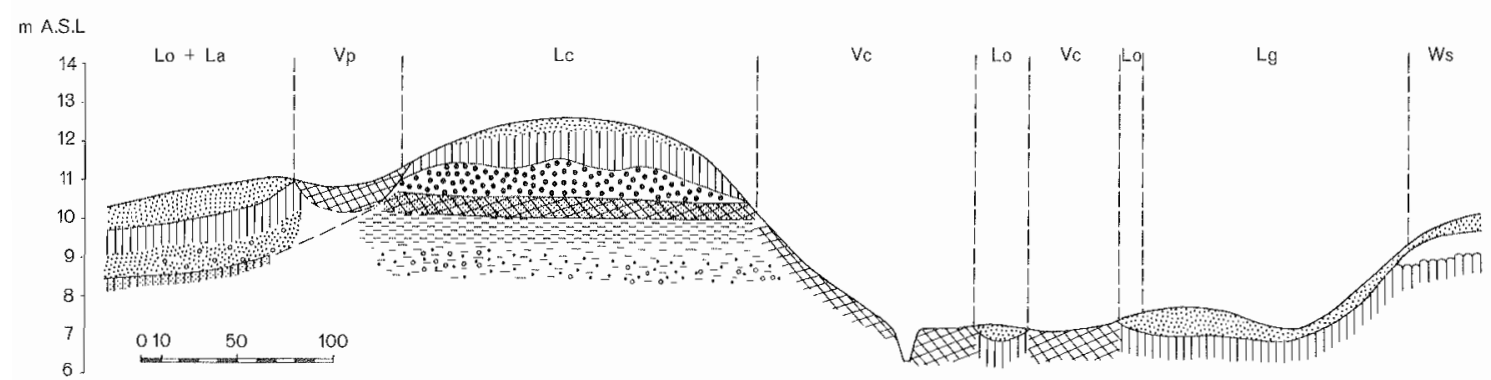

Fig. 5: Sediments and soils in part of section I - II, for the legend see fig. 4 . 

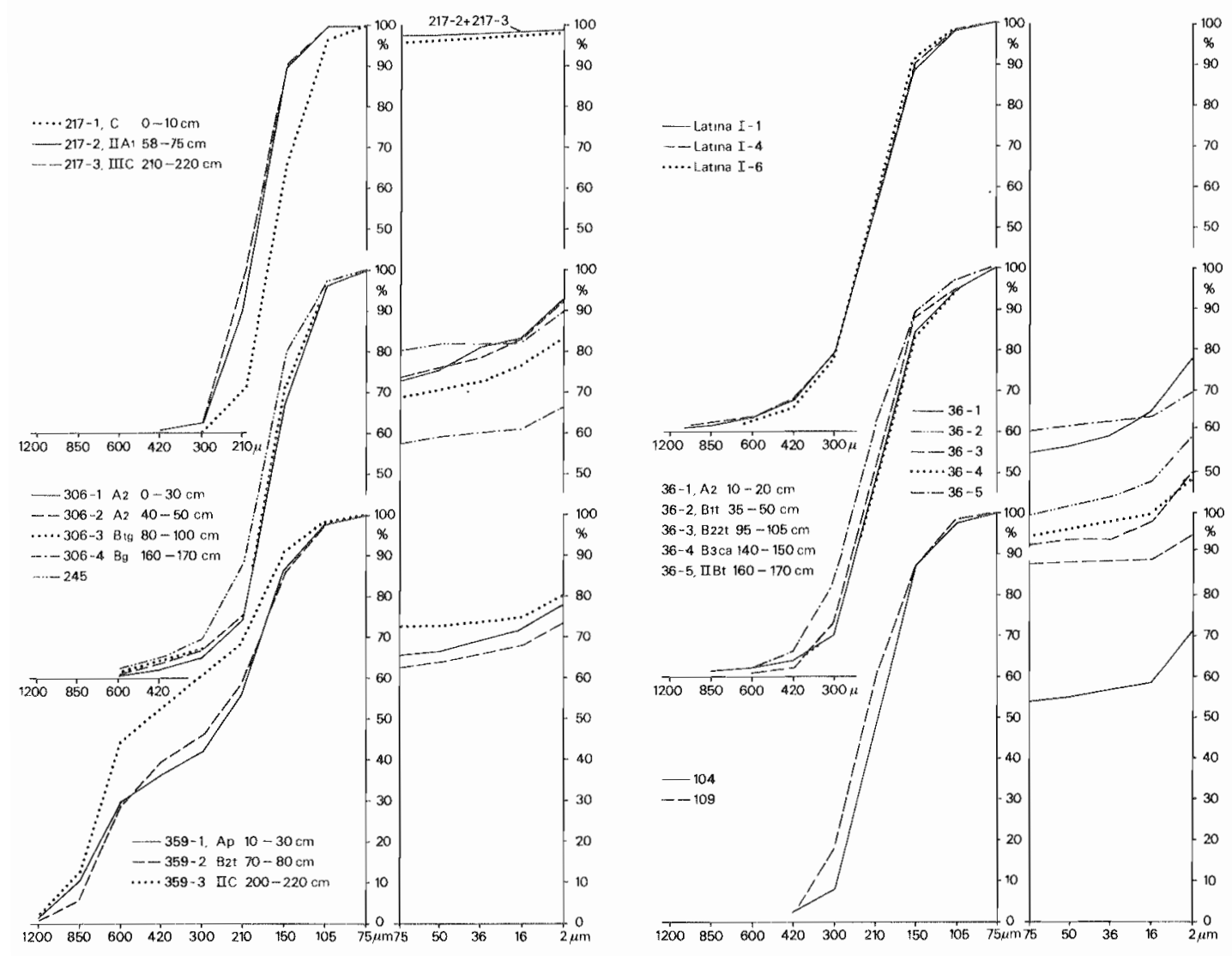

Fig. 6: Grain-size distribution of a number of soil profiles and materials. The fractions coarser than 75 um have been recalculated to 100 per cent. To the right, parts of the cumulative grain-size distributions of the fine-earth fractions are presented.

\subsection{THE LATINA COMPLEX}

Only part of this extensive complex has been studied during this survey. It consists of a dissected level plateau, 20 to 25 ma.s.1. The boundary with the Minturno complex is formed by a scarp, which is highest and best expressed in the SE and poorly discernable in the NW. In this scarp as well as in the steep river incisions the upper strata of the Latina complex are well exposed. These consist of horizontally bedded well sorted fine augitic sands with rare intercalations of clay lenses and beds. Any interbedded paleosols are lacking. Borings for groundwater exploration, carried out at several locations inside as well as outside of the area studied, showed that these sands are very homogeneous and, at depths of 12 to $15 \mathrm{~m}$, are locally underlain by a complex of fossiliferous predominantly medium to fine textured beds, with some intercalated peat and marl beds. For analyses, see figure 6 (104 and 105, sandy beds). For the fauna see table 1.

On the more level and less eroded parts of the Latina complex, the augitic sands are covered by a layer of greenish clay to sandy clay loam, generally between 150 and $300 \mathrm{~cm}$ thick 
$s$

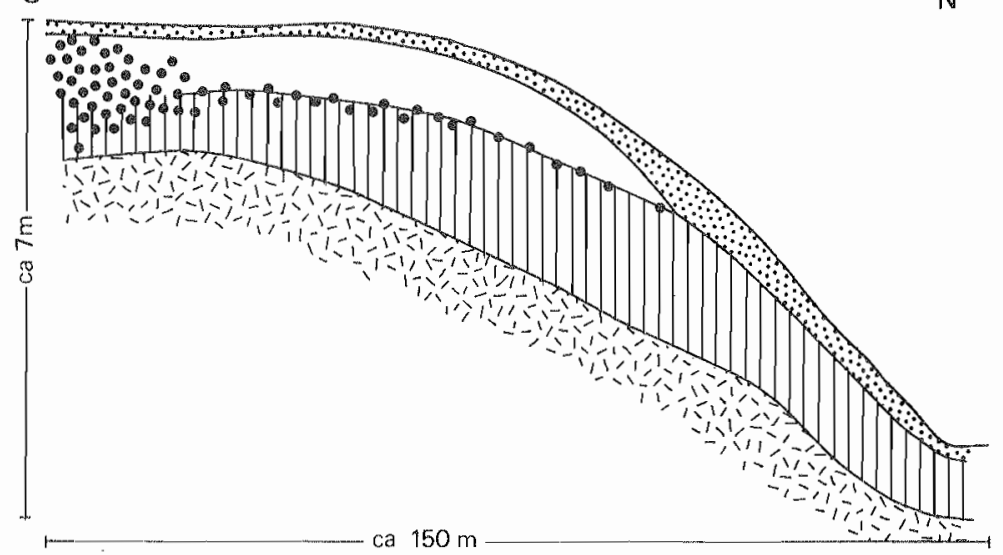

Fig. 7: Soil characteristics along section III, for the legend see fig. 4.

and with strong pseudogley features and vertic characteristics. No distinct pattern could be observed in the textural variations within this layer, which over large areas is covered by a discontinuous layer of bleached albic loamy sand, locally more than $50 \mathrm{~cm}$ thick.

The origin of the sandy deposits, forming the bulk of the Latina level, is somewhat uncertain. Evidently a beachridge system is lacking and an eolian origin, as inferred by earlier investigators, can be completely excluded: Diatom analyses (REMMELZWAAL 1978 and SEVINK et al.) point to deposition in a brackish/marine environment and the other characteristics - intercalations of clayey beds and channel fills, the horizontal parallel bedding, the presence of shells in the lower beds and the texture are incompatible with a littoral or eolian origin as well as with a coastal lacustrine origin (see e.g. VAN STRAATEN 1965).

When sands overly clay, Planosols dominate. In figure 6 grainsize analyses are presented for such a profile (profile 36). Sand on top of more loamy deposits generally gave rise to Albic and Gleyic Luvisols, both with strong pseudogleying. In the absence of sand Chromic Vertisols to Gleyic Luvisols occur. Soils on topographically lower positions within the level area may show strong accumulations of Fe-Mn oxides and hydroxides. An exceptional case was observed in section III where an extreme accumulation of Fe-Mn took the form of a petroferric horizon (see figure 7).

\subsection{THE FLUVIAL INCISIONS}

In the preceding paragraphs the fluvial incisions are only briefly mentioned. These were mainly formed during regressions i.e. periods of low sea level, and will be discussed in more detail here. For sake of brevity they have been named as follows: in the Borgo Ermada complex: system I; the larger river system draining the Latina complex: system II; and the Fosso di Moscarello system: system III (see figure 2).

System I consists of a series of parallel streams, which only near their junction have incised. Borings in these incisions showed that they may exceed depths of more than $5 \mathrm{~m}$ and that these were later filled in by lagoonal deposits (see figure 4). 

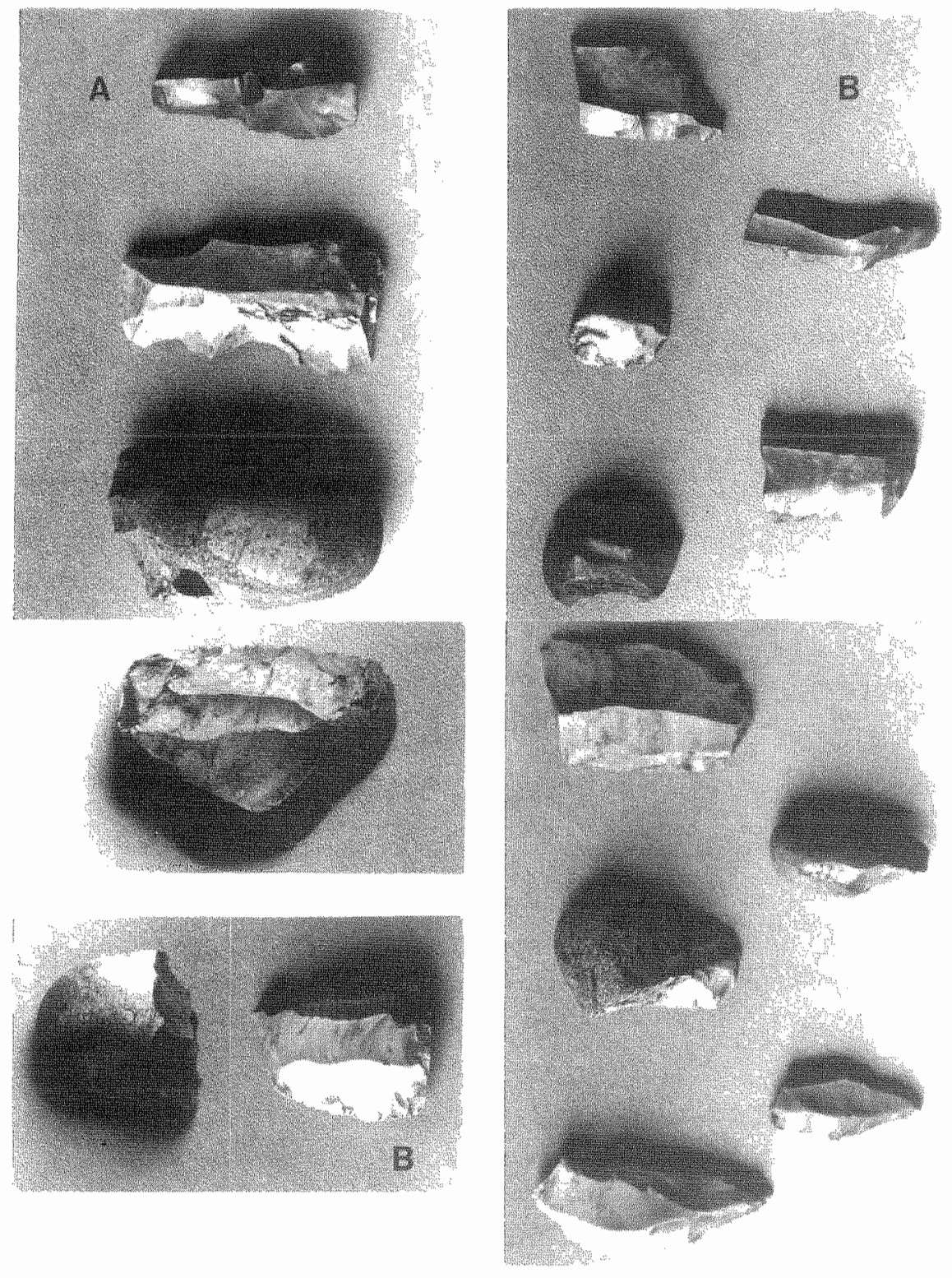

Photo 1: Prehistoric tools from the Minturno beachridge near Cerreto Alto (site A) and near the fattoria Colle Parito (site B).

A: Site A, B: Site B, scale $0 \quad 1 \quad 2 \mathrm{~cm}$ 
System II is more complex. Within the Latina complex the valley slopes can be divided into two parts: an upper relatively gentle part with well developed soils, resembling those on the more level parts of the scarp - Gleyic and Chromic Luvisols - and a steep lower part with weakly developed soils - Regosols (see figure 7). Valley infills are insignificant. In the Minturno complex the valleys are mostly flat-bottomed. The valley floors are underlain by fine-textured often peaty deposits, containing anthropogenic materials (flint, pottery and charcoal). No evidence was found for the presence of deposits forming part of the Borgo Ermada complex.

System III has been strongly altered by man. It is, however, still clear that it represents one of the major river systems draining the Latina complex. The upper part of the vally fill consists of clayey fluvial deposits of relatively recent age (partially ripened). To the W of Borgo Sabatino the deposits in the Fosso di Moscarello were observed to overlie sands with intercalated paleosols forming part of the eolian cover of the Borgo Ermada level. However, to the NE of this village eolian sands were found in borings to cover peaty infills of older incisions, forming part of the Fosso di Moscarello system. Ostensibly, the eolian deposits in this area date from several phases.

\subsection{PREHISTORICMATERIALS}

Scattered flint fragments (flakes and tools) were encountered in top soils all over the Minturno and Latina complexes. On the Borgo Ermada complex however, flint artefacts were very scarce, while non was observed on the Terracina complex. Concentrations of flint artefacts (see photo 1) were found at the surface on the sandy ridge of the Minturno level: near Cerreto alto, presumably Pontinian type pebble tools and Mousterian tools, and near the Fattoria Colle Parito SE of the area studied a very large concentration of presumably Pontinian type tools and Mousterian tools, with in addition Aurignacian type tools (oral communications D. STAPERT). The paleolithic tools have a strong patina. At both sites in addition presumably Mesolithic or Neolithic flint tools without patina were observed. A concentration of flint fragments, which was too small to allow statements on its age, was observed near the Cantoria delle Vergini, around a shallow depression with Pellic Vertisols. Current investigations by a group of prehistorians indicate that Mousterian type tools abound on the Minturno and Latina complex and are virtually absent on the younger complexes.

\section{DISCUSSION AND CONCLUSIONS}

Within the area studied, four separate complexes, i.e. marine terraces, can be distinguished, the altitude of which increases with age. The Terracina complex represents a rather simple beachridge-lagoon system, as commonly observed along the present Mediterranean coast. The Minturno complex has a similar rather simple beachridge and lagoon-structure. The Borgo Ermada complex, however, has an entirely different structure as it consists of a series of elongated sand ridges with intermediate fine-textured lagoonal deposits. The Latina complex represents an incomplete system of which at least the beachridge has been eroded. Whether the predominantly sandy deposits were formed in an open marine or lagoonal environment is not clear, but the latter seems more likely. Apartfrom the fluvial incisions of system III, the incisions are clearly related to the morphology of the marine complexes. In the western part of the area eolian sands, deposited in several phases, 
cover the marine complexes, in particular the Borgo Ermada complex. They conceal the original coastal morphology and fill in earlier fluvial incisions.

The deposits of the Borgo Ermada complex transgress over the frontal part of the Minturno complex without a major hiatus as indicated by the presence of a well-preserved buried soil. The elongated sandy ridges are at least partially bedded in fine-textured lagoonal deposits and their altitude decreases towards the present coast. In our opinion, this structure can only be explained by assuming that the system was formed during a minor regressive phase (subsequent on the earlier transgression, phase g), in which the relative sea level fell (phase h) and beachridges and lagoons were repeatedly formed at decreasing altitudes. Unfortunately relevant studies of regressive coastal developments in the Mediterranean area could not be found in the literature and, therefore, comparison is impossible. From the observations on the incisions in the Borgo Ermada complex, a subsequent major regression must be inferred (phase j).

The abundant occurrence of gravel in the lower strata of the Minturno complex is striking. In the Latina complex gravel beds or beds, relatively rich in gravel, were never encountered. However, taking into account the shape and dimensions of the Latina complex, coarsetextured littoral and beachridge deposits are likely to have occurred to the SW of the present complex and to have acted as a source of gravel in a later phase. Another possible source of gravel are the Tertiary deposits near Nettuno, which are known to contain siliceous gravel. These gravels may have been transported by longshore currents. However, such gravels are lacking along the present coast. Fluvial supply can be completely excluded as rivers of significant capacity were lacking.

The bedding of the gravels - parallel and low angle - and the presence in the deeper strata of large tuff and tuffaceous sandstone fragments with abundant boreholes clearly suggest deposition in a littorial environment near a high energy beach during a transgressive phase (phase d). Thus the genesis of the gravel beds in our opinion can be best explained by residual accumulation of gravels through strong abrasion of older, gravel containing deposits, probably forming part of the Latina complex and their subsequent deposition in a littoral environment along a cliff-like coast. The "fining-upwards" on top of the gravel beds, together with the seaward development of a beachridge point to a regressive coastal development with a rising relative sea level (phased), an evolution comparable to that during the Holocene. The sea level has fluctuated in that later period (phase e), as indicated by the local presence of paleosols below (Luvisols) and in (Vertisols) the clayey top layer, which contains shells and corals. In a final stage (phase e) the beachridge migrated inland over the lagoon. Subsequently the sea retreated (phase f), as suggested by the presence of a buried soil, in the frontal part of the beachridge, covered by deposits of the Borgo Ermada complex (see figure 5).

Sequences of marine terraces as observed in the area studied are common in the Mediterranean area. Theirgenesis is generally related to glacioeustaticand tectonoeustaticsea level changes (see for example FAIRBRIDGE 1972). However, as stressed by HEY(1977) the possibility of local tectonic movements should always be taken into account. Several observations in the area studied indicate that such movements played a role.

The regressive character of the Borgo Ermada complex essentially can result from syndepositional glacioeustatic sea level lowering or from local tectonic uplifting. A comparison with adjacent areas shows that in those areas the Borgo Ermada complex or related deposits are on the whole of very small extent and consist of simple beachridge-lagoon or littoral systems (REMMELZWAAL 1978, CONATO \& DAI PRA 1980). Consequently, a local syndepositional uplift seems most likely.

Proof for a minor tectonic tilting was found in the adjacent Minturno complex: the sur-- 
face of the clayey lagoonal deposits clearly dips to the SW and disappears beneath the beachridge. The highest altitudes at which lagoonal deposits were observed, i.e. close to the Latina level, exceed those of the highest parts of the beachridge and this phenomenon cannot be attributed to later erosion.

It is likely that this tilting, creating a gradient towards the $\mathrm{SW}$, is also responsible for the regressive character of the Borgo Ermada complex. Because of this tilting, altitudinal correlations are problematic, but correlation with sequences of re- and transgressive phases remains possible (see for example BUTZER 1975 and HEY 1977).

The differences in soil characteristics are primarily related to differences in texture, drainage and age. In sandy deposits, if freely drained, soils with a reddish-brown argillic horizon are developed, whereas in clayey materials soils develop towards Chromic Verticols. In intermediate materials soils with mottled argillic horizons are formed, generally with an albic horizon. In table 2 a scheme is presented showing the major relationships. These are in accor-

Tab. 2: MAJOR CHARACTERISTICS AND CLASSIFICATION OF THE SOILS ON THE MARINE COMPLEXES.

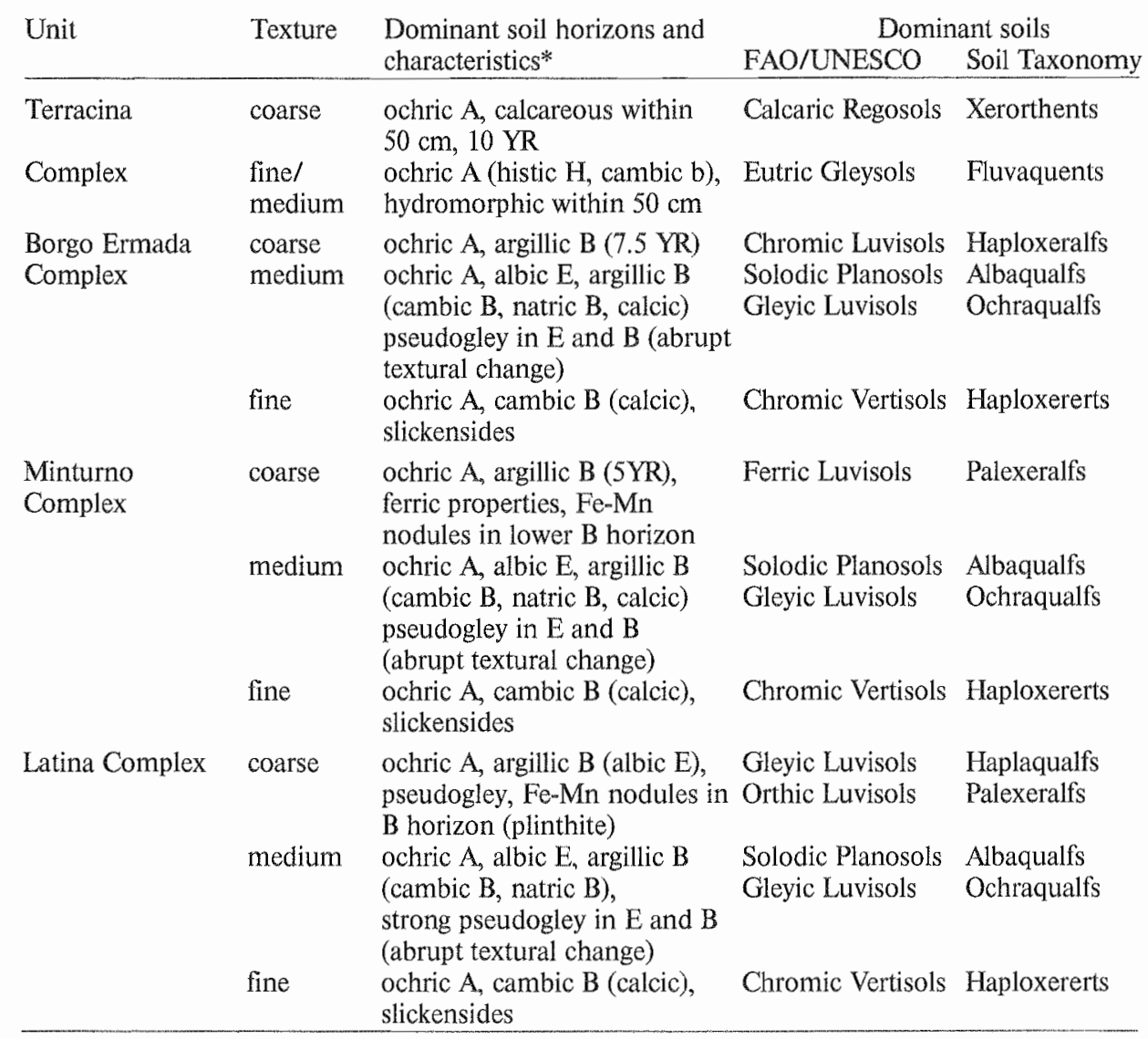

* If indicated between ( ), the characteristics or horizons are common to rare. 
dance with those found by REMMELZWAAL (1978). Most interesting for dating purposes, are the soils in sandy deposits, which together form a perfect chronosequence. Each of the complexes has its own characteristic soils, which proves that they represent individual complexes of different age. In the medium and fine textured sediments such clear chronosequences are absent.

Our observations on the soils in medium textured deposits indicate that the textural profiles observed - sand over clay to sand clay - basically are inherited from the parent material. These are as follows:

a) Particularly on the Borgo Ermada complex, but also elsewhere, the thickness of the sandy albic top layer has no relation to the texture of the underlying $B$ horizon.

b) In the level areas the sandy top layer is discontinuous and this phenomenon cannot be attributed to later erosion (see for example the description of the Borgo Ermada level).

c) The best developed Planosols occur adjacent to the areas with thick eolian sand covers.

d) Well developed Planosols occur on all pre-Holocene complexes and there is no relationship between their development and age.

e) In Planosols on the Minturno complex primary carbonates (shells and corals) occur at shallow depths, indicating that vertical leaching played a very subordinate role in their genesis.

Our conclusion therefore is that the textural changes in the top of the profiles are largely inherited from the parent material and that the sands most probably are of eolian origin. REMMELZWAAL (1978), who studied a number of Planosols on the Latina complex, holds to the opinion that the textural profiles are due to pedogenetic processes in originally uniform sediments, a theory which is in conflict with out observations.

Absolute dating of the pre-Holocene complexes and phases is impossible as none of the actual methods can be applied. Dating on the basis of the observed faunas (see table 1) is impossible. Strombus bubonius was not observed and, even if present, would not allow more than a tentative dating of Tyrrhenian age (BONADONNA\& BIGAZZI 1970, BIGAZZI et al. 1973, REMMELZWAAL 1978). Until now dated chronosequences in sandy deposits in Central-Italy are lacking (see REMMELZWAAL 1978) and therefore the sequence can only be used for relative dating.

More promising is the correlation with known marine terrace sequences. In northern Latium a sequence of raised beaches was found at 2-3 m, 10-15 $\mathrm{m}$ and 18-25 $\mathrm{m}$ a.s.1. They were described and dated by BIGAZZI et al. (1973) as Strombus III (approx. 90.000 Y.B.P.), STROMBUS II (approx. 127.000 Y.B.P.) and STROMBUS I (dated approx. 200.000 Y.B.P.) raised beaches. The dates are somewhat tentative (see REMMELZWAAL 1978), but correspond very well with those of marine transgressions observed and studied elsewhere, as for example on Barbados (SHACKLETON \& MATTHEWS 1977) and Mallorca (BUTZER 1975). The sequence of re- and transgressions postdating the Latina complex resembles the sequences of BUTZER (see table 3) and BIGAZZI et al. to such an extent that we conclude that the Borgo Ermada complex probably dates from the Strombus III c.q. Tyrrhenian III transgression and the Minturno complex of the Strombus II c.q. Tyrrhenian II transgression. The eolian sands accordingly date from the Middle and Late Würmian and might correlate with the eolianites of Hemicycle B of BUTZER (1975). The tentative dating by REMMELZWAAL (1978) of the Borgo Ermada and Minturno complex as of respectively Eemian and Holsteinian ages, thus in our opinion is incorrect.

Correlation of the Latina complex with the Strombus I raised beach is dangerous, as it cannot be excluded that beachridge-lagoon systems existed intermediately between the Latina and Minturno complexes, which were completely eroded during the regression(s) of 
Tab. 3: SCHEME OF THE SEA LEVEL CHANGES, SEDIMENTARY COMPLEXES, SOIL CHRONOSEQUENCES AND THEIR TENTATIVE DATING IN THE COASTAL AREA NEAR LATINA.

\begin{tabular}{|c|c|c|c|}
\hline Phases & Sediments & $\begin{array}{l}\text { Soils in sandy deposits } \\
\text { (with thickness of } \\
\text { solum and hue) }\end{array}$ & Tentative age \\
\hline Transgression (k) & Terracina Complex & $\begin{array}{l}\text { Calcaric Regosols } \\
(0.5 \mathrm{~m}, 10 \mathrm{YR})\end{array}$ & Holocene \\
\hline $\begin{array}{l}\text { Major regression (j) and } \\
\text { several phases of eolian } \\
\text { activity (i) }\end{array}$ & Eolian sands & $\begin{array}{l}\text { Cambic Arenosols } \\
(0.5-1 \mathrm{~m}, 10 \mathrm{YR}) \text { to } \\
\text { Chromic Luvisols } \\
(1 \mathrm{~m}, 7.5 \mathrm{YR})\end{array}$ & Würmian \\
\hline $\begin{array}{l}\text { Minor regression, possibly } \\
\text { of tectonic origin (h), } \\
\text { Transgression }(\mathrm{g})\end{array}$ & $\begin{array}{l}\text { Borgo Ermada } \\
\text { Complex }\end{array}$ & $\begin{array}{l}\text { Chromic Luvisols } \\
(2 \mathrm{~m}, 7.5 \mathrm{YR})\end{array}$ & Tyrrhenian III \\
\hline Minor regression (f) & - & - & Early Würmian \\
\hline $\begin{array}{l}\text { Late minor fluctuations (e) } \\
\text { Transgression (d) }\end{array}$ & Minturno Complex & $\begin{array}{l}\text { ferric Luvisols } \\
(4 \mathrm{~m}, 5 \mathrm{VR})\end{array}$ & Tyrrhenian II \\
\hline Major regression (c) & - & - & $?$ \\
\hline $\begin{array}{l}\text { Late minor fluctuations (b) } \\
\text { transgression (a) }\end{array}$ & Latina Complex & $\begin{array}{l}\text { Albic Gleyic Luvisols } \\
( \pm 4 \mathrm{~m}, 5-7.5 \text { YR })\end{array}$ & $?$ \\
\hline
\end{tabular}

phase c. The abundant presence of volcanic minerals, however, points to a deposition contemporaneous with or immediately following the latest major eruptive phase of the Vulcano Laziale. Future absolute datings of tuffs, covered by deposits of the Latina complex, to the NW of Latina, will enable a more accurate dating of this complex.

On the basis of our observations and conclusions, the observations of BLANC on the type locality "Gniff-Gnaff" can be re-interpreted. The deposits concerned are situated in and along the deep fluvial incision of the Fosso di Moscarello near the boundary between the Latina and Minturno complex. The section consists of peaty deposits, containing a terrestrial fauna and flora and Pontinian type artefacts, on top of fossiliferous marine sands and covered by presumably eolian sands with intercalated paleosols.

Evidence for the presence of an important stratigraphic hiatus between the marine sands and overlying peaty deposits are lacking, for which reasons BLANC considers the marine sands to date from the latest, Pleistocene, transgressive phase. The sands therefore would form part of the Borgo Ermada complex and consequently would date from the Strombus III (e.c. Tyrrhenian III) transgression, approx. 90.000 Y.B.P. Such a dating agrees well with the apparent C-14 date $-58.000 \pm 500$ Y.B.P. - of one of the lower peat beds (VOGEL \& ZAGWIJN 1967), but implies that the dating by BLANC - Tyrrhenian II - is incorrect. The sands and overlying strata would thus represent a Strombus III transgressional and subsequent regressional infilling of an old incision.

Our research illustrates that minor sea level changes may result from local tectonic movements and that these can interfere with the altitudinal correlation of terraces as well as with the identification of sediment complexes as individual marine terraces. Soil chronosequences in that case may provide a clue: the identification of the Borgo Ermada and Min. turno complex as separate terraces is largely based on the chronosequence of soils in sandy materials. 


\section{ACKNOWLEDGEMENTS}

The authors wish to express their gratitude to Dr. H.E. Coomans for the identification of the faunas and to Drs. A.M.H. Arnoldus-Huijzendveld for her assistance in the field. Thanks are due to Dr. A.C. Imeson for the correction of the english text, to Mrs. O.M. Bergmeijer-de Vré for drawing the figures and to Mrs. M.C.G. Keijzer-v.d.Lubbe for typing the manuscript.

\section{RETERENCES}

BIGAZZI, G., BONADONNA, F.P. \& IACCARINO, S. (1973): Geochronological hypothesis on PlioPleistocene boundary in Latium region (Italy). Boll. Soc. Geol. It., 92, 391-422.

BLANC, A.C. (1936): Sulla stratigrafia quaternaria dell'Agro Pontino e della bassa Versilia. Boll. Soc Geol. It., 55, 375-396.

BLANC, A.C., VRIES, H. de \& FOLLIERI, M. (1957): A first date for the Würm I Chronology on the Italian Coast. Quaternaria, IV, 83-94.

BLANC, A.C. (1962): Sur le Pleistocène marin des côtes tyrrhéniennes et ioniennes et les cultures paleolithiques associées. Quaternaria, 6, 371-389.

BONADONNA, F.P. \& BIGAZZI, G. (1970): Studi sul Pleistocene del Lazio VIII: Datazioni di tufi intertirreniani della zona di Cerveteri (Roma) mediante il metodo della trace di fissione. Boll. Soc. Geol. It., 89, 439-444.

BUTZER, K.W. (1975): Pleistocene littoral-sedimentary cycles of the Mediterranean basin: a Mallorquien view. In: BUTZER, K.W. \& ISAAC, G.L. (ed.): After the Australopithecines. Mouton, The Hague, 5-71.

CONATO, V. \& DAI PRA, G. (1980): Livelli marini pleistocenici e neotettonica fra Civitavecchia Tarquina (Italia Centrale). Laboratorio di Geologia Ambientale, C.N.E.N., Roma, Internal Report no. MNTLT/5/80, $31 \mathrm{p}$

CONFORTE, B., RICCIO, G. di \& SAPPA, M. Indagine sulle aque sotterranee dell'Agro Romano e Pontino (parte 2 - Agro Pontino); Cassa per opere straordinarie di pubblico interesse nell'Italia Meridionale (Cassa per il Mezzogiorno), $45 \mathrm{p}$.

DESSING, M. (1972): Landschap en bodem in de Agro Pontino, Latina, Italia. Unpublished postgraduate thesis, Amsterdam, $77 \mathrm{p}$.

FAIRBRIDGE, R.W. (1972): Quaternary sedimentation in the Mediterranean region controlled by tectonics, paleoclimates and sea level. In: STANLEY, D.J. (ed.): The Mediterranean Sea, 2nd Int. Sed. Congr., Heidelberg, 1971: Dowden, Hutchinson and Ross, Stroudsberg, Pa, USA 99-113.

FAO-UNESCO (1974): Soil Map of the World, 1:5.000.000, Vol. 1, Legend. Unesco, Paris, $59 \mathrm{p}$

HEY, R.W. (1977): The marine Quaternary of the Mediterranean. Stud. Geol. Polonica, 52, 170-176.

REMMELZWAAL, A. (1978): Soil genesis and Quaternary landscape development in the Tyrrhenian coastal area of South-Central Italy. Thesis, Amsterdam, $309 \mathrm{p}$

SEVINK, J. (1977): Het bodemonderzoek in de Fysische Geografie. K.N.A.G. Geografisch Tijdschrift, XI, nr. 3, 189-194.

SEVINK, J., REMMELZWAAL, A. \& SPAARGAREN, O.C.: The soils of southern Lazio and adjacent Campania. In preparation.

SHACKLETON, N.J. \& MATTHEWS, R.K. (1977): Oxygen isotope stratigraphy of the late Pleistocene coral terraces in Barbados. Nature, 268, 618-620.

SOIL SURVEY STAFF (1975): Soil Taxonomy. U.S. Dept. Agric. Handb. 436, Washington, 754 p.

STRAATEN, L.M.J.U. van (1965): Coastal barrier deposits in south and north Holland, in particular in the area around Scheveningen and IJmuiden. Meded. Geol. Sticht. N.S., 17, 41-75.

UNESCO-FAO (1963): Bioclimatic map of the Mediterranean zone. Arid Zone Res. 21, 58 p.

VOGEL, J.C. \& ZAGWIJN, W.H. (1967): Groningen Radiocarbon Dates VI. Radiocarbon, Yale, 9, 63-106.

Anschrift der Autoren:

J. Sevink, Laboratory for Physical Geography and Soil Science, Dapperstraat 115, Amsterdam,

The Netherlands

P. Vos, W.E. Westerhoff, A. Stierman, Instituut voor Aardwetenschappen, Vrije Universiteit,

Afd. Kwartairgeologie, De Boelelaan 1085, Amsterdam--Buitenveldert, The Netherlands

H. Kamermans, Albert Egges van Giffen Instituut voor Pre- en Protohistorie, Singel 453,

Amsterdam-C, The Netherlands 